Brit. J. Ophthal. (1960) 44, 64.

\title{
CORRESPONDENCE
}

\section{SOLAR RETINITIS}

To the Editorial Committee of the British JouRnal of Ophthalmology

SIRS,-I have read with great interest the article on solar retinitis by L. P. Agarwal and S. R. K. Malik (Brit. J. Ophthal., 1959, 43, 366), in which the lesions are classified into four grades. In this connexion, may I refer to my observations on solar retinitis (Nirankari, 1954), which are quoted by these authors, and also to those of Das, Nirankari, and Chaddah (1956). My colleagues and I classified the lesions according to the degree of burning produced by the solar rays, and for the first time (as far as we know) assigned them to four grades. The authors of the present article have confirmed our observations, the only difference being that we think the lesions to be due to the degree of burning produced by the intensity of the heat rays concentrated in a small area of the macula while the present authors attach importance to the spasm of the vessels.

Yours faithfully,

M. S. NiRANKARI.

DePartment of OphTHALMology,

Medical College,

AMRITSAR, INDIA.

November 5, 1959.

\section{REFERENCES}

Das, T., NiRankari, M. S. and Chaddah, M. R. (1956). Amer. J. Ophthal., 41, 1048.

NIRANKARI, M. S. (1954). Trans. ophthal. Soc. U.K., 74, 276.

\section{BOOK REVIEW}

Ophthalmic Nursing. M. Whiting. 7th edition, 1959. Pp. 135, 58 figs. Churchill, London. $10 s$.

This well-known manual of ophthalmic nursing has now come to its 7 th edition wherein the text has been brought up to date. Its value as a guide to nurses in the treatment of ophthalmic cases is so well recognised as to make a detailed review unnecessary.

\section{NOTES}

\section{International Congress, 1962}

The XIX International Congress of Ophthalmology will be held from December 3rd to 7th, 1962 at Vigyan Bhuvah, New Delhi.

Full information may be obtained from the Secretary General, Dr. Y. K. C. Pandit, Bombay Mutual Bldg., Sir P. Mehta Road, Bombay 1, India. 